\title{
Viral lysis of Phaeocystis pouchetii and bacterial secondary production
}

\author{
Gunnar Bratbak $^{1, *}$, Anita Jacobsen ${ }^{2}$, Mikal Heldal $^{1}$ \\ ${ }^{1}$ Department of Microbiology, University of Bergen, Jahnebakken 5, N-5020 Bergen, Norway \\ ${ }^{2}$ Department of Fisheries and Marine Biology, University of Bergen, Bergen High Technology Centre, \\ N-5020 Bergen, Norway
}

\begin{abstract}
In this experimental study we investigated the effect of viral infection on primary production and carbon flow in a phytoplankton-DOC-bacteria food chain during viral lysis of the phytoplankton population. The phytoplankter host-virus system used was Phaeocystis pouchetii (Prymnesiophyceae) and the virus PpV01. Viral infection allowed primary production in the cells to continue throughout most of the lytic cycle. In non-infected algal cultures, net production of DOC and bacterial biomass was low and at the end of the experiment the DOC concentration was 10 to $20 \%$, and the bacterial biomass 0.5 to $4 \%$ of the algal carbon biomass. The amount of DOC released during viral lysis of the algal cells implies that the entire algal biomass was converted to DOC. Growth of bacteria succeeding cell lysis and release of DOC in virus infected cultures demonstrated that the net effect of the virus infection was an efficient conversion of algal biomass into bacterial biomass.
\end{abstract}

KEY WORDS: Phaeocystis pouchetii - Virus - DOC · Bacteria - Microbial food web

\section{INTRODUCTION}

The microbial loop, in which dissolved organic carbon (DOC) lost from phytoplankton is assimilated by bacteria and transferred back to the grazing food chain via bacterivorous microzooplankton, has been recognized as an important pathway in the microbial food web of aquatic ecosystems (Azam et al. 1983, 1993). Some 20 to $50 \%$ of the primary production is typically found to pass through the microbial loop (Cole et al. 1988).

Phytoplankton excretion and zooplankton grazing and sloppy feeding have been considered as the quantitatively most important internal sources of DOC in natural waters (Ducklow \& Carlson 1992, Fuhrman 1992). It has recently been suggested that viral infection causing cell lysis may be of importance to carbon and nutrient flow in the microbial food web (Fuhrman \& Suttle 1993, Bratbak et al. 1994, Suttle 1994). The observations which have led to this suggestion are the

•E-mail: gunnar.bratbak@im.uib.no high and variable abundance of virus and virus-like particles in aquatic environments, and the occurrence of such particles intracellular in a variable fraction of natural phytoplankton and bacterial communities.

The abundance of viruses and virus-like particles (VLP) in aquatic marine ecosystems is typically in the order of $10^{6}$ to $10^{8} \mathrm{ml}^{-1}$ (Maranger \& Bird 1995). Most of these viruses are presumably bacteriophages (Bratbak et al. 1990) but phycoviruses and viruses infecting other microorganisms may also be present in significant numbers (Proctor \& Fuhrman 1990, Bratbak et al. 1993, Suttle \& Chan 1993, 1995, Waterbury \& Valois 1993). Electron microscopy studies of microorganisms in natural waters have revealed that 1 to $40 \%$ of the bacterial community (Bratbak et al. 1994), and a variety of eucaryotic microorganisms (van Etten et al. 1991, Reisser 1993, Zingone 1995) contain virus-like particles. Total counts of viruses have been found to vary significantly in time and space, and have been correlated to biological parameters such as chlorophyll a concentration, bacterial abundance and bacterial activity (Bratbak et al. 1994, Maranger \& Bird 1995). The methods used to assess the rate of viral lysis 
of bacteria in natural waters are uncertain, but they indicate that a considerable fraction $(<10$ to $>50 \%)$ of the daily bacterial biomass production is diverted into dissolved material (Proctor et al. 1993, Bratbak \& Heldal 1995, Hennes \& Simon 1995, Mathias et al. 1995). There is also growing evidence that virus infection is a quantitative significant cause of mortality in many phytoplankton populations (Proctor \& Fuhrman 1990, Bratbak et al. 1993, 1995, Waterbury \& Valois 1993, Cottrell \& Suttle 1995, Brussaard et al. 1996). Virusinduced cell lysis may thus be a sizable source of DOC in natural environments.

A virus lytic to the marine haptophyte Phaeocystis pouchetii has recently been brought into culture (Jacobsen et al. 1996). Phaeocystis is an ecologically important phytoplankton genus in many areas (Lancelot et al. 1994) and may completely dominate spring blooms in regions as different in temperature, light conditions, nutrient status, and water column stability as e.g. the Barents Sea (Loeng et al. 1987) and the North Sea coast of the European continent (Lancelot et al. 1987). Phaeocystis from such blooms may sink (Wassmann et al. 1990, Wassmann 1994) or be consumed by predators (Admiraal \& Venekamp 1986, Huntley et al. 1987, Estep et al. 1990), but the collapse of such blooms has also been found to leave high concentrations of dissolved carbohydrates and organic nitrogen compounds in the photic zone (Eberlein et al. 1985), as one would expect if blooms terminate due to massive cell lysis. Since the mechanism of bloom collapse may be expected to strongly influence the postbloom concentrations of organic and inorganic nutrients in the photic zone, the whole post-bloom successional pattern of new phytoplankton species, heterotrophic bacteria, and protozoan predators would be expected to depend on the relative dominance of the different bloom-terminating mechanisms.

Virus infection and cell lysis of algae will inevitably have a major impact on the cells' $\mathrm{CO}_{2}$ fixation and on carbon flow in the foodweb. The purpose of this experimental study was to investigate the carbon flow and population dynamics in a phytoplanktonDOC-bacteria food chain during viral lysis of the phytoplankton population. The effect of viral infection on primary production was examined by measuring ${ }^{14} \mathrm{C}-\mathrm{CO}_{2}$ fixation in infected and non-infected algal cultures. The specific questions we have approached are related to timing of events and to magnitude and rate of carbon flow: At what stage in the lytic cycle is the $\mathrm{CO}_{2}$ fixation shut down? How much of and how fast is the cellular biomass converted to dissolved material during cell lysis? Is the organic material released during cell lysis readily available for bacterial secondary production or does it accumulate in the water?

\section{MATERIALS AND METHODS}

Cultures. The algal host-virus system used in this study was Phaeocystis pouchetii (Prymnesiophyceae) strain AJ01, obtained from the culture collection at the University of Bergen, Norway. This Phaeocystis strain does not form colonies under the growth conditions used in this study. The lytic virus PpV01 was isolated from Raunefjorden, Western Norway (Jacobsen et al. 1996). The algal culture and virus lysate were not axenic.

The cells were grown in a sterile filtered $(0.2 \mu \mathrm{m})$ sea water medium prepared from aged sea water (33\%) with vitamin and trace element additions as for the $f / 2$ medium (Guillard 1975). Nitrate and phosphate were added from autoclaved stock solutions to give final concentrations of $80 \mu \mathrm{M} \mathrm{NaNO}$ and $5 \mu \mathrm{M} \mathrm{KH}_{2} \mathrm{PO}_{4}$. For all experiments we used 1 \& cultures growing in 21 Erlenmeyer flasks. The incubation temperature was $8^{\circ} \mathrm{C}$ and the illumination (continuous light) from white fluorescent tubes was 40 to $50 \mu \mathrm{mol} \mathrm{m} \mathrm{m}^{-2} \mathrm{~s}^{-1}$ measured at the surface of the cultures. The cultures were gently swirled once a day to prevent sedimentation.

Experimental design. For the carbon flow studies we used four $1 \mathrm{l}$ batch cultures of exponentially growing Phaeocystis pouchetii. Two of the cultures were inoculated with a fresh virus lysate to give an initial virus-tohost ratio of 0.1 to 0.2 . The remaining 2 cultures served as control and received lysate that had been $0.2 \mu \mathrm{m}$ filtered to remove bacteria and heated to boiling in a microwave oven to inactivate the viruses.

To investigate the effect of virus infection on photosynthesis we measured the rate of ${ }^{14} \mathrm{C}-\mathrm{CO}_{2}$ incorporation at several time-points before and after inoculating an exponentially growing Phaeocystis pouchetii culture with a fresh virus lysate to give an initial virus-tohost ratio of about 10. A non-infected culture was used as control. Samples for cell and virus counts, and for analysis of inorganic and dissolved organic carbon, were analyzed as described below.

${ }^{14} \mathrm{C}$ incubations. $\mathrm{CO}_{2}$ incorporation was measured in triplicate by adding $1 \mu \mathrm{Ci}{ }^{14} \mathrm{C}-\mathrm{CO}_{2}$ (New England Nuclear) to $10 \mathrm{ml}$ samples and incubating for $1 \mathrm{~h}$ under the conditions described above. $5 \mathrm{mil}$ from each parallel was transferred to scintillation vials, acidified with 2 drops of $8 \mathrm{~N} \mathrm{HCl}$ and left open for $>24 \mathrm{~h}$ to remove unincorporated $\mathrm{CO}_{2}$. Controls were acidified immediately after isotope addition. Independent tests showed that no $\mathrm{CO}_{2}$ remained in the acidified samples after $24 \mathrm{~h}$. The samples were neutralized by adding 2 drops of $8 \mathrm{~N} \mathrm{NaOH}$ and the radioactivity measured in a Packard Tri-Carb scintillation counter after adding $5 \mathrm{ml}$ Ultima Gold XR (Packard) scintillation cocktail.

Enumeration and chemical analysis. Growth of the algae was monitored by live cell counts in a Fuchs Rosenthal haematocytometer. Samples for total count- 
ing of bacteria and viruses were preserved with $2.5 \%$ glutaraldehyde. Particles were harvested onto electron microscope grids ( $\mathrm{Ni}, 400$ mesh) by centrifugation and prepared for counting in the transmission electron microscope (TEM) basically as described earlier (Bratbak \& Heldal 1993). The centrifuge tubes we used were cut to accommodate ca $3 \mathrm{ml}$ of sample water and the samples were centrifuged for $30 \mathrm{~min}$ at $200000 \times \mathrm{g}$ in a Beckman SW 41 swing-out rotor. The grids were positive stained with $2 \%$ uranyl acetate and viewed in a Jeol 100CX or a Jeol 100 S TEM at $20000 \times$ magnification. Carbon biomass of algae and bacteria was estimated from volume measurements in phase contrast microscope (algae) and in TEM (bacteria).

DOC and inorganic carbon (IC) were measured in a Shimadzu TOC-5000 total organic carbon analyzer. Samples for DOC analysis ( 3 parallels of $5 \mathrm{ml}$ ) were filtered through $0.2 \mu \mathrm{m}$ Supor 200 filters (Gelman Sciences), preserved with $50 \mu \mathrm{l} 0.5 \mathrm{~N} \mathrm{HCl}$ and stored at $4^{\circ} \mathrm{C}$ until analysis. The initial DOC concentration in the seawater medium was $2.65 \mathrm{mgC}^{-1}$. This amount was subtracted from all DOC values measured throughout the experiment to focus on net changes. Samples for IC analysis ( 3 parallels of $5 \mathrm{ml}$ ) were measured immediately after sampling.

\section{RESULTS AND DISCUSSION}

\section{Biomass of algae and bacteria}

Measured in the phase contrast microscope the mean size of living Phaeocystis pouchetii cells was about $5 \mu \mathrm{m}$ in diameter (range 4 to $6 \mu \mathrm{m}$ ) from which we estimate a carbon content of $6.5 \mathrm{pgC}^{-1} \mathrm{cell}^{-1}$, assuming a cell density of 1 and a $10 \%$ carbon-to-wet weight ratio. Measured in the TEM, the mean volume of glutaraldehyde preserved bacteria was $0.3 \pm 0.03 \mu^{3}$ (mean $\pm \mathrm{SE}, \mathrm{n}=19$ ). Choosing a conservative volume

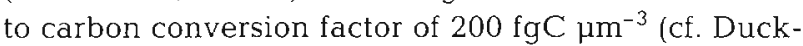
low \& Carlson 1992, Fuhrman 1992) we arrive at a mean bacterial carbon content of $60 \mathrm{fgC} \mathrm{cell}^{-1}$. In preliminary experiments the carbon content in single cells of $P$. pouchetii and of bacteria growing in the culture was (Heldal et al. 1985, Norland et al. 1995) found to be $5.6 \pm 0.8 \mathrm{pgC} \mathrm{cell}^{-1}$ and $62 \pm 7 \mathrm{fgC} \mathrm{cell}^{-1}$ (mean $\pm \mathrm{SE}$ ) respectively by quantitative $X$-ray microanalysis. The biomass estimates obtained by X-ray microanalysis and by volume measurements were thus in agreement both for algae and for bacteria. The number of cells sized was too low to reveal any significant changes in cell volume throughout the experiment and we thus adopt $6 \mathrm{pgC}$ algal cell ${ }^{-1}$ and $60 \mathrm{fgC}^{\text {bacterial cell }} \mathrm{l}^{-1}$ as conversion factors to estimate the carbon content of the respective populations from cell counts (Fig. 1).

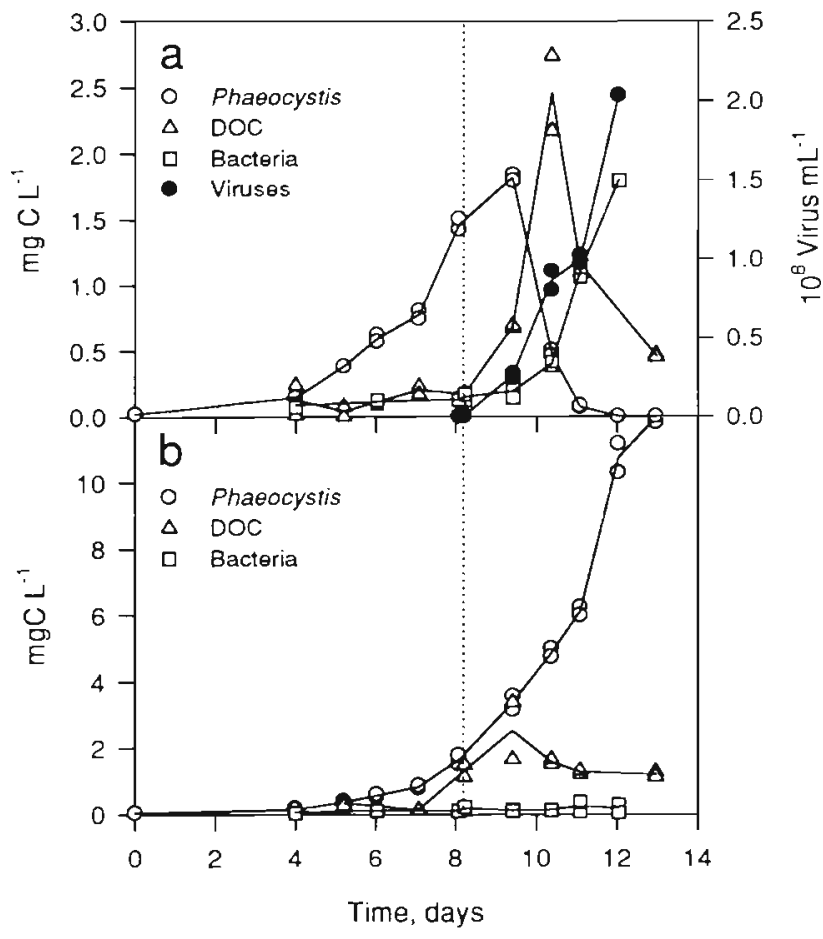

Fig. 1. Carbon flow experiment. (a) Carbon flow and population dynamics in 2 parallel cultures of Phaeocystis pouchetif infected with PpV01 virus at Day 8. (b) Carbon flow and population dynamics in 2 parallel non-infected (control) cultures. A background DOC concentration in the medium of $2.65 \mathrm{mgC}$ $1^{-1}$ was subtracted from all DOC values to focus on net changes. Dotted vertical line marks the time of virus addition

\section{Carbon flow}

Viral infection perturbed the exponential growth and decimated the Phaeocystis population within 3 d (Fig. 1a) while in the non-infected culture growth continued undisturbed (Fig. 1b). Virus-like particles were never observed in the non-infected cultures, suggesting that there was no background of non-virus virus-like particles in the cultures and that the non-infected control cultures were indeed uninfected. The concentration of DOC and the abundance of bacteria showed no significant changes in any of the cultures before the addition of viruses (Fig. 1a). The concentration of DOC increased when the algae lysed and this increase was followed by an increase in bacterial abundance (Fig. 1a). The same successional pattern between algae, DOC and bacteria was observed during a lysis induced decline of a Phaeocystis spring bloom in the North Sea (van Boekel et al. 1992). At the end of the experiment (Days 11 to 13 ) the amount of DOC and of bacterial biomass was 10 to 20 and 0.5 to $4 \%$ respectively compared to the algal carbon biomass. In the non-infected culture there was no substantial increase in DOC or bacterial biomass compared to the algal biomass (Fig. 1b). 
The peak in algal biomass in the infected culture was $1.8 \mathrm{mgC} \mathrm{l}^{-1}$, but 0.5 to $0.6 \mathrm{mgC}^{-1}$ was then already released as DOC due to viral lysis of the cells. The initial increase in viral abundance (Days 8.1 to 9.4) was $2.6 \times 10^{7}$ viruses $\mathrm{ml}^{-1}$ which corresponds to a loss of ca $9 \times 10^{4}$ algal cells $\mathrm{ml}^{-1}$ or $0.6 \mathrm{mgC} \mathrm{l}^{-1}$ assuming an average burst size of 270 viruses per cell. The latter figure was estimated from the first net decrease in algal cells and the concurrent increase in viruses (Days 9.4 to 10.4). The estimated loss in algal biomass is in agreement with the observed net increase in DOC of $0.5 \mathrm{mgC} \mathrm{I}^{-1}$ between the addition of virus and the peak in algal biomass. The total algal biomass production may thus be estimated to have been about $2.4 \mathrm{mgC}^{-1}$ which compares well with the observed maximum DOC concentration of $2.45 \mathrm{mgC}^{-1}$.

The bacterial biomass was $1.8 \mathrm{mgC}^{-1}$ when sampling for this parameter was terminated (Day 12). The DOC concentration was at this time still above background concentration (i.e. above $2.65 \mathrm{mgC} \mathrm{l}^{-1}$ ) and further bacterial growth may thus have taken place.

The ratio between DOC produced and algal biomass produced was close to 1 , indicating that the entire algal biomass was converted to DOC upon cell lysis (Fig. 1). The ratio between bacterial biomass produced and DOC produced was as high as 0.7 although the bacterial biomass production may have been underestimated. In this carbon budget we have not accounted for extracellular organic polymers or slime which is not particulate in the sense of cellular nor dissolved in the sense that it passes the $0.2 \mu \mathrm{m}$ filters used to separate particulate and dissolved material. Algal production and bacterial utilization of such material may explain the apparently high bacterial growth efficiency. The overall conclusion is nevertheless that algal carbon released upon viral lysis was efficiently converted to bacterial biomass.

For viral infection of Aureococcus anophagefferens, Gobler et al. (1997) estimated that accumulated bacterial carbon secondary production was $22 \%$ of the carbon in the cells lost during lysis. The amount of carbon released into the dissolved phase amounted to $15 \%$ of the algal carbon. Compared to our results with Phaeocystis pouchetti, this suggests that both the amount and bioavailability of organic material released from algae due to viral lysis, and the bacterial secondary production succeeding such lysis, may vary significantly.

\section{Effect of virus infection on $\mathrm{CO}_{2}$ fixation}

The changes in cell abundance in the infected and non-infected cultures are shown in Fig. 2a. There was a lag in cell growth in the non-infected culture from 0 to $12 \mathrm{~h}$ which we interpret to have been caused by

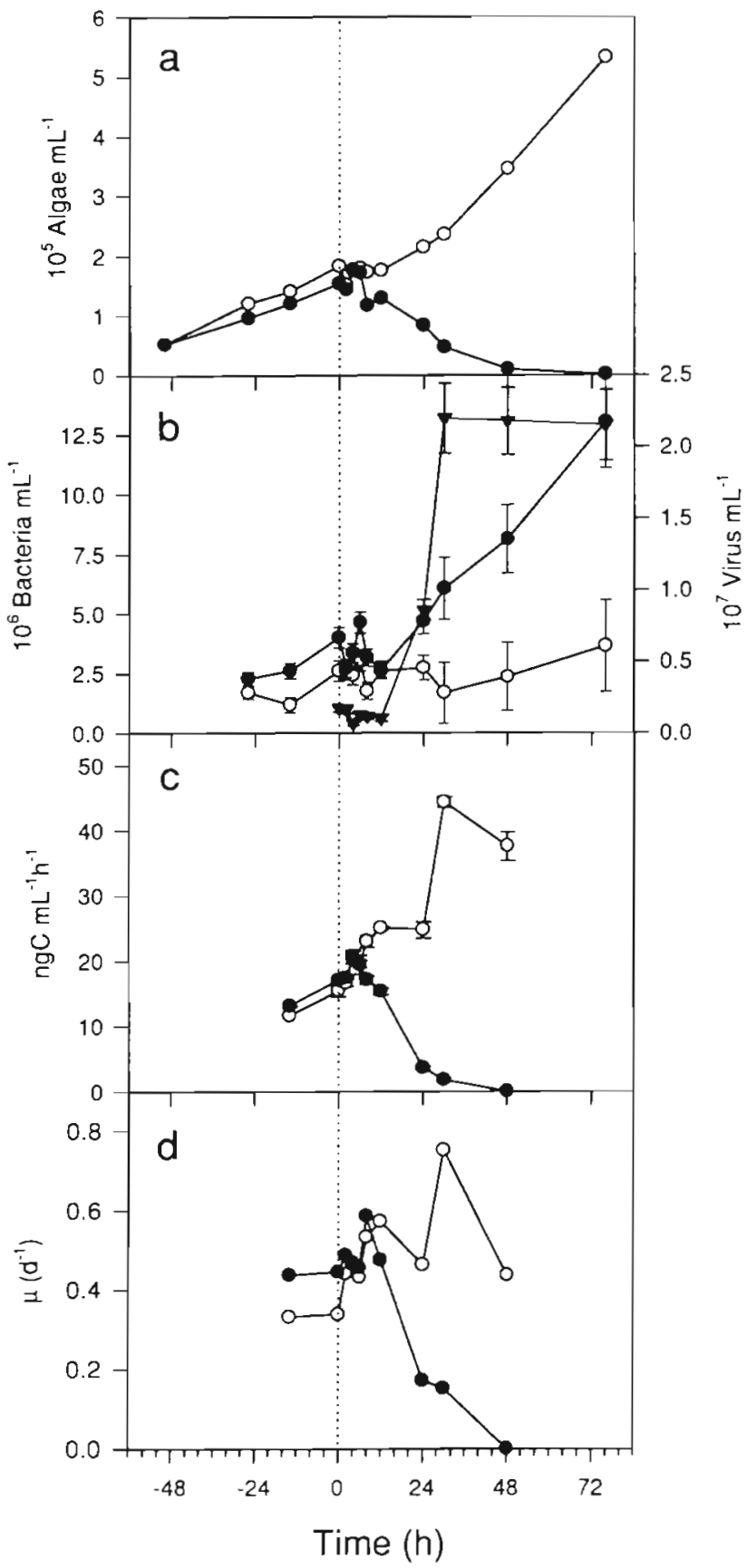

Fig. 2. Effect of virus infection on primary production. Dotted vertical line marks the time of virus addition to the experimental culture. (a) Abundance of Phaeocystis pouchetii in the infected ( $\bullet$ and the non-infected (control) (O) cultures. (b) Abundance of PpV01 virus ( $\mathbf{v}$ ) in the infected culture and of bacteria in infected ( $\bullet$ ) and the non-infected (control) (0) culture. Error bars are counting error $(1 / \mathrm{N} n, \mathrm{n}=$ number of viruses counted). (c) Primary production measured as ${ }^{14} \mathrm{C}$ $\mathrm{CO}_{2}$ fixation in the infected ( $)$ and the non-infected (control) (o) culture. Error bars are standard error of mean of 3 parallels (errors less than the size of the symbols are not shown). (d) Growth rate in the infected $(\bullet)$ and the non-infected (control) (o) culture estimated from primary production and a cellular carbon content of $6 \mathrm{pgC} \mathrm{cell-1}$ 
frequent sampling and disturbance of the culture. Fig. $2 \mathrm{~b}$ shows that the abundance of free viruses increases rapidly between 12 and 24 h and reaches a maximum between 24 and $30 \mathrm{~h}$. With an initial virusto-host ratio of 10 and a lytic cycle of 12 to $18 \mathrm{~h}$ (Jacobsen et al. 1996) this indicates that most or all of the algal cells were infected shortly after the addition of the viruses. Virus-like particles were never observed in the non-infected culture.

The rate of $\mathrm{CO}_{2}$ fixation in both the virus infected and the non-infected culture (Fig. 2c) reflects the change in cell abundance in the 2 cultures. From increase in cell numbers we estimated the growth rate $\left(\mu, \mathrm{d}^{-1}\right)$ of uninfected algae (both cultures) to be $0.42 \pm$ $0.02 \mathrm{~d}^{-1}$ (mean $\pm \mathrm{SE}, \mathrm{n}=17$ ). From the rate of $\mathrm{CO}_{2}$ fixation (Fig. 2c) and the biomass, which was calculated from cell number (Fig. 2a) and a cell carbon content of $6 \mathrm{pgC} \mathrm{cell}{ }^{-1}$, we estimate a mean growth rate of $0.48 \pm$ $0.04 \mathrm{~d}^{-1}$ (mean $\pm \mathrm{SEM}, \mathrm{n}=10$ ) for the non-infected culture (Fig. 2d). The mean growth rate estimated for the infected culture was $0.48 \pm 0.07 \mathrm{~d}^{-1}$ (mean \pm SEM, $\mathrm{n}=7$ ) until $12 \mathrm{~h}$ after infection, i.e. the same as in the non-infected culture (Fig. 2d). The photosynthetic apparatus of the infected cells does thus seem to be active during most of the lytic cycle which lasts for 12 to $18 \mathrm{~h}$ (Jacobsen et al. 1996). In this respect the Phaeocystis-PpV host-virus system resembles virus infection in Synechococcus where the photosynthetic rate in infected cultures was similar to that in non-infected control cultures until near the onset of cell lysis (Suttle \& Chan 1993). This is however not a universal feature. The rate of photosynthesis in Micromonas pusilla has been found to be significantly reduced within $2 \mathrm{~h}$ after infection, but in part maintained until near the end of the lytic cycle (Waters \& Chan 1982). In Chlorella infected with $\mathrm{PBCV}-1$ virus, $\mathrm{CO}_{2}$ fixation is inhibited almost immediately (van Etten et al. 1983).

The difference between the growth rate estimated from increase in cell abundance and the growth rate estimated from $\mathrm{CO}_{2}$ fixation was insignificant. The former approach includes only production of new cells, i.e. the particulate production, while the latter, which is based on total $\mathrm{CO}_{2}$ fixation, includes both particulate and dissolved production. We may thus interpret these results to indicate that the production of DOC, except for that caused by viral lysis, was only a small fraction of the particulate production.

\section{Ecological considerations}

The bacteria in these experiments are those which have been carried over and co-cultured with the Phaeocystis since it was originally isolated. It may thus be assumed that they are pre-selected and well adapted to grow on organic material released from these algae. Accordingly, the lag period before onset of bacterial growth after input of organic material from algal cell lysis may be expected to be short, and the bacterial growth efficiency on this material may be expected to be high. Natural bacterial communities that are not specifically selected and adapted for growing on organic material released from lysed algal cells may show a longer lag period before onset of growth and perhaps also a lower growth efficiency than observed in these experiments. There is however no reason to believe that the natural community will have a qualitatively different response.

Excretion and leaching from intact phytoplankton cells and byproducts of zooplankton ingestion and digestion have been recognized as the main pathways of DOC from phytoplankton to bacteria (Jumars et al. 1989). Virus-induced cell lysis may nevertheless for short periods of time most certainly represent a much larger input of DOC to the system. The difference between these pathways, i.e. slow and steady release of DOC versus massive cell lysis with sudden release of large amounts of DOC, may be of significant ecological relevance. The former pathways may select for bacteria growing steadily on a relatively low and constant input of carbon (K-strategy) while the latter may select for those who have the ability to respond quickly and grow fast on relatively high concentrations of organic material (r-strategy). Viral lysis of a blooming phytoplankton community may thus be hypothesized to result in a shift in the bacterial community composition.

Acknowledgements. This work was supported by funding from The European Commission to the MAST-III Project MEDEA, contract number MAS3-CT95-0016 and by funding from The Research Council of Norway, project number $113037 / 120$ and 121425/420. We thank Evy Foss Skjoldal, Jorunn Viken and Gunhild Bødtker for their excellent technical assistance. The EM work was done at the Laboratory for Electron Microscopy. University of Bergen.

\section{LITERATURE CITED}

Admiraal W, Venekamp LAH (1986) Significance of tintinnid grazing during blooms of Phaeocystis pouchetii (Haptophyceae) in Dutch coastal waters. Neth J Sea Res 20: 61-66

Azam F, Fenchel T, Field JG, Gray JS, Meyer-Reil LA, Thingstad TF (1983) The ecological role of water-column microbes in the sea. Mar Ecol Prog Ser 10:257-263

Azam F, Smith DC, Steward GF, Hagström $\AA$ (1993) Bacteriaorganic matter coupling and its significance for oceanic carbon cycling. Microb Ecol 28:167-179

Bratbak G, Egge JK, Heldal M (1993) Viral mortality of the marine alga Emiliania huxleyi (Haptophyceae) and termination of algal blooms. Mar Ecol Prog Ser 93:39-48

Bratbak G, Heldal M (1993) Total count of viruses in aquatic environments In: Kemp PF, Sherr BF, Sherr EB, Cole JJ (eds) Current methods in aquatic microbial ecology. Lewis 
Publishers, London, p 135-138

Bratbak G, Heldal M (1995) Viruses - the new players in the game; their ecological role and could they mediate genetic exchange by transduction? [n: Joint I (ed) Molecular ecology of aquatic microbes. NATO ASI (Adv Sci Inst) Ser Ser $G$ Ecol Sci 38:249-264

Bratbak G, Heldal M, Norland S, Thingstad TF (1990) Viruses as partners in spring bloom microbial trophodynamics. Appl Environ Microbiol 56:1400-1405

Bratbak G, Heldal M, Thingstad T (1994) Viruses and the microbial loop. Microb Ecol 28:209-221

Bratbak G, Levasseur M, Michaud S, Cantin G, Fernández E, Heimdal BR, Heldal M (1995) Viral activity in relation to Emiliania huxleyi blooms: a possible mechanism of DMSP release? Mar Ecol Prog Ser 128:133-142

Brussaard CPD, Kempers RS, Kop AJ, Riegman R, Heldal M (1996) Virus like particles in a summer bloom of Emiliania huxleyi in the North Sea. Aquat Microb Ecol 10:105-113

Cole JJ, Findlay F, Pace RL (1988) Bacterial production in fresh and salt water ecosystems: a cross-system overview. Mar Ecol Prog Ser 43:1-10

Cottrell MT, Suttle CA. (1995) Dynamics of a lytic virus infecting the photosynthetic marine picoflagellate Micromonas pusilla. Limnol Oceanogr 40:730-739

Ducklow HW, Carlson CA (1992) Oceanic bacterial production. Adv Microb Ecol 12:113-181

Eberlein K, Leal MT, Hammer KD, Hickel W (1985) Dissolved organic substances during a Phaeocystis pouchetii bloom in the German Bight (North Sea). Mar Biol 89:311-316

Estep K, Nejstgaard JL, Skjoldal HR, Rey F (1990) Predation by copepods upon natural populations of Phaeocystis pouchetii as a function of the physiological state of the prey. Mar Ecol Prog Ser 67:235-249

Fuhrman J (1992) Bacterioplankton roles in cycling of organic matter: the microbial food web. In: Falkowski PG, Woodhead $A D$ (eds) Primary productivity and biogeochemical cycles in the sea. Plenum Press, New York, p 361-383

Fuhrman JA, Suttle CA (1993) Viruses in marine planktonic systems. Oceanography 6(2):51-63

Gobler CJ, Hutchins DA, Fisher NS, Cosper EM, Sañudo-Wilhelmy SA (1997) Release and bioavailability of C, N, P, Se and Fe following viral lysis of a marine chrysophyte. Limnol Oceanogr 42:1492-1504

Guillard RRL (1975) Culture of phytoplankton for feeding marine invertebrates. In: Smith WL, Chanley $\mathrm{MH}$ (eds) Culture of marine invertebrate animals. Plenum Press, New York, p 29-60

Heldal M, Norland S, Tumyr O (1985) X-ray microanalytical method for measurement of dry matter and elemental content of individual bacteria. Appl Environ Microbiol 50: $1251-1257$

Hennes KP, Simon M (1995) Significance of bacteriophages for controlling bacterioplankton growth in a mesotrophic lake. Appl Environ Microbiol 61:333-340

Huntley M, Tande K, Eilertsen HC (1987) On the trophic fate of Phaeocystis pouchetii (Hariot). II Grazing rates of Calanus hyperboreus (Krøyer) on diatoms and different size categories of Phaeocystis pouchetii. J Exp Mar Biol Ecol 110:197-212

Jacobsen A, Bratbak G, Heldal M (1996) Isolation and characterisation of a virus infecting Phaeocystis pouchetii (Prymnesiophyceae). J Phycol 32:923-927

Jumars PA, Penry DL, Baross JA, Perry MJ, Frost BW (1989) Closing the microbial loop: dissolved carbon pathway to heterotrophic bacteria from incomplete ingestion, digestion and adsorption in animals. Deep-Sea Res 36:483-495

Editorial responsibility: John Dolan.

Villefranche-sur-Mer, France
Lancelot $C$, Billen $G$, Sournia A, Weisse $T$, Colijn $F$, Veldhuis M, Davies A, Wassmann P (1987) Phaeocystis blooms and nutrient enrichment in the continental coastal zones of the North Sea. Ambio 16:38-46

Lancelot C, Wassmann P, Barth H (1994) Ecology of Phaeocystis-dominated ecosystems. J Mar Syst 5:1-4

Loeng $H$, Rey $F$, Skjoldal HR (1987) Physical and biological oceanographic features across the polar front in the western Barents Sea. In: Ros J (ed) Persistent frontal systems. 22nd Eur Mar Biol Symp 17-22 August 1987, Barcelona Sci Mar 53

Maranger R, Bird DF (1995) Viral abundance in aquatic systems: a comparison between marine and fresh waters. Mar Ecol Prog Ser 121:217-226

Mathias CB, Kirschner AKT, Velimirov B (1995) Seasonal variation of virus abundance and viral control of the bacterial production in a backwater system of the Danube River. Appl Environ Microbiol 61:3734-3740

Norland S, Fagerbakke KM, Heldal M (1995) Light element analysis of individual bacteria by $\mathrm{X}$-ray microanalysis. Appl Environ Microbiol 61:1357-1362

Proctor LM Fuhrman JA (1990) Viral mortality of marine bacteria and cyanobacteria. Nature 343:60-62

Proctor LM, Okubo A, Fuhrman JA (1993) Calibrating estimates of phage-induced mortality in marine bacteria: ultrastructural studies of marine bacteriophage development from one-step growth experiments. Microb Ecol 25 $161-182$

Reisser W (1993) Viruses and virus-like particles of freshwater and marine eucaryotic algae - a review. Arch Protistenkd 143:257-265

Suttle CA (1994) The significance of viruses to mortality in aquatic microbial communities. Microb Ecol 28:237-243

Suttle CA, Chan AM (1993) Marine cyanophages infecting oceanic and coastal strains of Synechococcus: abundance, morphology, cross-infectivity and growth characteristics. Mar Ecol Prog Ser 92:99-109

Suttle CA, Chan AM (1995) Viruses infecting the marine prymnesiophyte Chrysochromulina spp.: isolation preliminary characterization and natural abundance. Mar Ecol Prog Ser 118:275-282

van Boekel WHM, Hansen FC, Riegman R, Bak RPM (1992) Lysis-induced decline of a Phaeocystis spring bloom and coupling with the microbial foodweb. Mar Ecol Prog Ser 81:269-276

van Etten JL, Burbank DE, Xia Y, Meints RH (1983) Growth cycle of a virus, PBCV-1, that infects Chlorella-like algae. Virology 126:117-125

van Etten JL, Lane LC, Meints RH (1991) Viruses and viruslike particles of eucaryotic algae. Microbiol Rev 55 $586-620$

Wassmann P (1994) Significance of sedimentation for the termination of Phaeocystis blooms. J Mar Syst 5:81-100

Wassmann P, Vernet M. Mitchell BG, Rey F (1990) Mass sedimentation of Phaeocystis pouchetii in the Barents Sea Mar Ecol Prog Ser 66:183-195

Waterbury JB, Valois FW (1993) Resistance to co-occurring phages enables marine Synechococcus communities to coexist with cyanophages abundant in seawater Appl Environ Microbiol 59:3393-3399

Waters RE, Chan AT (1982) Micromonas pusilla virus: the virus growth cycle and associated physiological events within the host cells; host range mutation. J Gen Virol 63 $199-206$

Zingone A (1995) The role of viruses in the dynamics of phytoplankton blooms. G Bot Ital 129:415-423

Submitted: March 31, 1998; Accepted: May 29, 1998

Proofs received from author(s): September 29, 1998 